Jurnal Keperawatan Silampari

Volume 5, Nomor 1, Desember 2021

e-ISSN: 2581-1975

p-ISSN: 2597-7482

DOI: https://doi.org/10.31539/jks.v5i1.3059

\title{
GAMBARAN RERATA KELELAHAN PADA PASIEN KANKER YANG MENJALANI KEMOTERAPI
}

\author{
Indah Marzalia Putri ${ }^{1}$, Nelwati ${ }^{2}$, Emil Huriani ${ }^{3}$ \\ Universitas Andalas ${ }^{1,2,3}$ \\ indahaja2412@ gmail.com ${ }^{1}$
}

\begin{abstract}
ABSTRAK
Penelitian ini bertujuan untuk mengetahui rerata skor kelelahan pada pasien kanker yang menjalani pengobatan kemoterapi di RSUP. Dr. M. Djamil Padang. Jenis penelitian yang digunakan adalah deskriptif kuantitatif. Hasil penelitian ini menunjukkan nilai rerata tingkat kelelahan responden adalah 28,78 dengan nilai minimum 19 dan maksimum 37 menggunakan 95\% CI. Jika dikatagorikan sebanyak 66,6\% responden mengalami kelelahan sedang dan sebanyak 33,4 \% mengalami kelelahan berat. Simpulan, nilai rerata tingkat kelelahan responden sebagian besar berada pada kategori kelelahan sedang dan hampir setengannya adalah kelehahan berat.
\end{abstract}

Kata Kunci: Kanker, Kelelahan, Kemoterapi

\section{ABSTRACT}

This study aims to determine the average fatigue score in cancer patients undergoing chemotherapy treatment at RSUP. Dr. M. Djamil Padang. The type of research used is descriptive quantitative. The results of this study indicate that the average value of the respondent's level of fatigue is 28.78, with a minimum value of 19 and a maximum of 37 using $95 \%$ CI. If categorized as $66.6 \%$ of respondents experienced moderate fatigue, and as many as $33.4 \%$ experienced severe fatigue. In conclusion, the average value of the respondents' fatigue level mainly was in the intermediate fatigue category, and almost half of them were extreme fatigue.

Keywords: Cancer, Fatigue, Chemotherapy

\section{PENDAHULUAN}

Menurut Yayasan Kanker Indonesia (2019) kanker adalah sebuah istilah yang digunakan untuk penyakit dimana pertumbuhan sel abnormal yang membelah tanpa kontrol dan menyerang jaringan lain. Setiap sebelas menit ada satu penduduk dunia yang meninggal karena kanker dan setiap tiga menit ada satu penderita kanker baru. Jumlah penderita kanker di seluruh dunia terus meningkat signifikan. Menurut Globocan (2018) prevalensi kanker meningkat dari 18,1 juta kasus kanker di tahun 2018 menjadi 19,3 kasus kanker pada tahun 2020 dan angka kematian sebesar 9,6 juta pada tahun 2018 sedangkan pada tahun 2020 sebesar 10.0 juta kasus kematian. Kanker dapat mengakibatkan efek yang besar bagi penderitanya, baik secara fisik, psiokologis, ekonomi maupun aspek kehidupan lainnya. Efek tersebut dipengaruhi oleh kualitas hidup penderita kanker. 
Kemoterapi merupakan pengobatan kanker untuk menghambat pertumbuhan selsel ganas dengan agen antikanker. Jenis terapi ini dapat digunakan untuk menyembuhkan dan sebagai bantuan paliatif pada stadium lanjut kanker (Alam, 2018). Efek samping kemoterapi muncul akibat obat-obatan kemoterapi sangat kuat, dan tidak hanya membunuh sel-sel kanker, tetapi juga menyerang sel-sel sehat, terutama sel-sel yang membelah dengan cepat. Efek samping yang umumnya dirasakan pasien diantaranya adalah kelelahan (Khairani et al., 2019).

Kelelahan atau yang disebut fatigue adalah suatu perasaan yang sangat lelah sepanjang waktu, tidak ada yang lebih baik dengan istirahat. Hal ini menjadi masalah selama pengobatan kanker. American Cancer Society (2019) kelelahan merupakan indikator yang berdampak parah serta dapat mempengaruhi kemampuan fungsional dan kualitas hidup pasien dengan semua jenis kanker. Gejala paling umum yang dialami pasien didefinisikan sebagai rasa lelah atau kelelahan fisik, emosional dan/atau kognitif, dan mengganggu aktivitas fisik (Fabi et al., 2020).

Kelelahan terkait kanker secara konsisten dinilai sebagai gejala yang paling sulit dipahami, umum, dan parah yang dialami pasien kanker yang menjalani kemoterapi. Strebkova et al., (2017); Dahlia et al., (2019) menjelaskan pengkajian kelelahan ini meliputi perasaan lemah, ketidakmampuan untuk melakukan aktivitas, motivasi menurun dan suasana hati yang rendah, serta kesulitan dalam berpikir jernih. Faktorfaktor yang dapat mempengaruhi atau memperburuk kelelahan pada pasien yang menjalani kemoterapi seperti usia, sosial, jenis kanker, stadium kanker, frekuensi kemoterapi, anemia, nyeri, depresi, tingkat kelelahan awal sebelum tindakan (Menga et al., 2020; Nitalia, 2019). Kelelahan pada pasien kemoterapi sering dialami namun jarang sekali tidak dilaporkan, kurang terdiagnosis sebagai masalah yang sangat penting dan tidak ditangani oleh petugas kesehatan (Marco et al., 2018).

Berdasarkan survei awal dan wawancara awal peneliti lakukan di ruang kemoterapi RSUP Dr. M. Djamil Padang pada bulan Juni 2021, hasil wawancara dengan perawat didapatkan belum ada form pengkajian kelelahan yang digunakan di ruang kemoterapi dan masih dilakukan dengan pernyataan subjektif. Berdasarkan wawancara dengan 6 respoden didapatkan bahwa 2 responden mengatakan kelelahan berupa kesulitan menaiki tangga, tidak merasa puas walaupun sudah istirahat dan tidur, kehilangan minat dalam pekerjaan, mudah tersinggung, 1 responden merasa lelah jika berjalan jarak jauh dan lelah melakukan aktivitas sehari-hari, 3 responden mengatakan merasa terganggu dalam menyelesaikan tugas, tidak fokus dan tidak pernah melakukan olahraga.

Setiap inidividu dapat mengalami kelelahan dalam tingkat keparahan yang berbeda. Kelelahan pada pasien kanker dengan kemoterapi dapat diklasifikasikan berdasarkan tingkatan yaitu berat, sedang dan ringan. Penelitian pada pasien kanker sudah pernah dilakukan, namun fokus pada penelitian ini adalah untuk melihat rerata kelelahanpada pasien kanker yang menjalani kemoterapi.

\section{METODE PENELITIAN}

Penelitian dilakukan di ruang kemoterapi RSUP. Dr. M. Djamil Padang dimulai bulan Juni 2021. Jenis penelitian ini adalah deskriptif kuantitatif. Dalam penelitian ini tidak ada pengontrolan variabel, maupun manipulasi atau perlakuan dari peneliti. Populasi pada penelitian ini adalah seluruh pasien kanker yang menjalani kemoterapi pada bulan Januari 2021 berjumlah 201 pasien. Sampel yang diteliti dihitung menggunakan rumus power analysis dalam aplikasi G*Power. Berdasarkan hasil 
perhitungan sampel menggunakan effect size calculation (medium effect) 0,3 untuk standar sample size 0,05 untuk error probability, dan 0,80 untuk power (1- $\beta$ eror probability) maka diperoleh sampel responden 67 orang. Untuk mengantisipasi drop out maka responden ditambah $10 \%$, jumlah sampel menjadi 72 orang. Pengambilan sampel menggunakan teknik convenience sampling dengan. Dalam penelitian ini menggunakan kuesioner Piper Fatigue Scale (PFS) untuk mengidentifikasi tingkat kelelahan terdiri atas domain afektif/emosional, perilaku dan kognitif/suasana hati.

\section{HASIL PENELITIAN}

Tabel. 1

Rerata Skor Kelelahan Pasien Kanker yang Menjalani Kemoterapi

\begin{tabular}{lccccc}
\hline Variabel & $\mathrm{n}$ & Mean & SD & Min-Maks & 95\% CI \\
\hline Kelelahan & 72 & 28,78 & $\pm 3,225$ & $19-37$ & $28,02-29,54$ \\
\hline
\end{tabular}

Dalam penelitian ini rerata skor kelelahan pada pasien kanker yang menjalani kemoterapi di RSUP Dr. M. Djamil Padang, nilai rata-rata tingkat kelelahan responden adalah 28,78 dengan nilai minimum 19 dan maksimum 37 menggunakan 95\% CI. Jika dikatagorikan sebanyak $66,6 \%$ responden mengalami kelelahan sedang dan sebanyak 33,4 \% mengalami kelelahan berat. Dengan nilai rata-rata perdomain adalah kelelahan afektif/emosional 11,0\%, perilaku 11,2\%, sedangkan rata-rata untuk kognitif/suasana hati adalah $6.58 \%$.

\section{PEMBAHASAN}

Kelelahan adalah gejala yang sangat sulit untuk didefinisikan, secara umum dapat dipahami sebagai perasaan subjektif dari kelemahan, kelelahan yang dikaitkan dengan aktifitas dan tidak hilang dengan istirahat (Khanghah et al., 2019). Hasil penelitian menunjukkan sebagian besar mengalami kelelahan tingkat sedang. Namun penelitian ini juga menemukan sebanyak 33,4\% mengalami kelelahan tingkat berat. Berdasarkan hasil penelitian Dahlia et al., (2019) menunjukkan bahwa responden pada fatigue tingkat ringan sebanyak $7,6 \%$, tingkat sedang sebanyak (50\%) dan tingkat berat sebanyak $42,4 \%$.

Hasil penelitian Rahma \& Ikhsanudin (2021) menunjukkan tingkat kelelahan yang dialami pasien kanker yang menjalani kemoterapi di RSUP H. Adam Malik Medan sebagian besar adalah kelelahan sedang yaitu sebanyak 35 responden $(53,8 \%)$. Hal ini disebabkan pasien kanker mendapatkan rejimen dari pengobatannya secara terus menerus, efek samping dari pengobatan seperti kemoterapi dapat menyebabkan mual, muntah, anemia dan mukositis. Berdasarkan stadium kanker mayoritas stadium 3 sebanyak 25 orang $(65,8 \%)$ dikategorikan lelah sedang dikarenakan faktor utama yang secara signifikan memperngaruhi kejadian dan intensitas cancer related fatigue adalah stadium kanker, stadium kanker yang lebih tinggi akan meningkatkan intensitas cancer related fatigue. Serta berdasarkan siklus kemoterapi mayoritas pada siklus 6 sebanyak 17 orang $(68,0 \%)$ kategori lelah sedang.

Penderita kanker sangat rentan terhadap kelelahan disebabkan rejimen kemoterapi yang yang mengakibatkan penekanan kortisol yang mempunyai dampak pada produksi sitokin, peningkatan kadar sitokin berkontribusi terhadap kelelahan (Wang et al., 2020). Fatigue terkait kanker merupakan kelelahan yang di ungkapkan pasien kanker bersifat 
menetap dan tidur tidak membuatnya membaik (National Comprehensive Cancer Network, 2018).

Kelelahan afektif/emosional adalah respon individu yang unik terhadap stress yang dialami diluar kelaziman pada hubungan interpersonal karena dorongan emosional yang kuat, timbul perasaan seakan-akan tidak ada individu yang membantunya, depresi, perasaan terbelenggu dan putusu asa (Muis et al., 2018). Pada hasil penelitian didapatkan rata-rata $11,0 \%$, responden merasa selalu bersemangat dalam melakukan aktivitas sehari-hari, miliki perasaan yang sabar, kadang-kadang memiliki emosi yang labil dan mudah tersinggung.

Kelelahan kognitif adalah indikator kelelahan kognitif meliputi ketidakberdayaan, kehilangan semangat, kehilangan makna hidup, kehilangan minat untuk bekerja, dan kesulitan berkonsentrasi. Kelelahan kognitif berdampak pada ketidakmampuan untuk berkonsentrasi, mudah lupa dan sulit membuat keputusan. (Pawicara \& Conilie, 2020). Pada hasil penelitian ini didapatkan rata-rata perilaku $11,2 \%$, responden merasa mampu mengingat sesuatu hal dengan baik, mampu berpikir dengan jernih dan kadang-kadang merasa sulit memahami pembicaraan orang lain.

Kelelahan perilaku merupakan penurunan fungsional yang dapat mempengaruhi kualitas hidup. Kelelahan pada pasien kanker dapat berdampak pada perilaku perawatan diri pasien (O'Regan et al., 2019). Wang et al., (2020) menggambarkan bahwa kemampuan perawatan diri yang baik dikaitkan dengan kelelahan yang lebih rendah. Hasil penelitian pada domain perilaku didapatkan rata-rata $6.58 \%$, responden merasa sering lemas dan lesu meskipun tanpa ataupun melakukan aktivitas, terganggu dalam melakukan aktivitas dan merasa memerlukan banyak tenaga untuk melakukan aktivitas, sering merasa memerlukan tenaga lebih baik dalam melakukan akitivitas dan waktu yang lebih banyak untuk istirahat.

Menurut Dahlia et al., (2018) menyebutkan bahwa efek kemoterapi menyebabkan adanya pelepasan zat-zat sitokin seperti TNF (Tumor Nekrosis Faktor) dan interleukin yang menyebabkan anoreksia. Anoreksia disebabkan karena sitokin seperti interleukin-1 (IL-1) dan Tumor Necrosis Factor-a (TNF) yang merupakan neurotransmiter yang menekan sistem saraf pusat pemicu penurunan nafsu makan. Hal ini menyebabkan penurunan berat badan dan massa otot serta anemia sehingga pasien kanker dengan stadium lanjut cenderung mengalami kelelahan.

Pengkajian kelelahan pada pasien kanker harus dilakukan secara multidisiplin dengan cara menyaring, menilai, serta mengelola data, sehingga tingkat kelelahan teridentifikasi dan tereksplorasi serta mengetahui faktor-faktor yang dapat meningkatkan kelelahan pada pasien kanker yang menjalani kemoterapi. Tingkat kelelahan yang berada pada skala sedang dan berat yang biasanya mengalami peningkatan dari waktu ke waktu karena proses pengobatan, maka profesi keperawatan dan pelayanan kesehatan lainnya sangat penting memberikan perhatian khusus atau memberikan terapi komplementer untuk mengatasi kelelahan tersebut, mengingat akan dampak dari kelelahan yang dialami oleh pasien yang menjalani kemoterapi akan berdampak kuat terhadap kualitas hidup sehari-hari.

\section{SIMPULAN}

Nilai rerata tingkat kelelahan responden sebagian besar berada pada kategori kelelahan sedang dan hampir setengannya adalah kelehahan berat. 


\section{SARAN}

Disarankan penelitian ini menjadi masukan dalam proses pemberian asuhan keperawatan dalam melakukan pengkajian kelelahan pada pasien yang menjalani kemoterapi. Bagi peneliti selanjutnya agar melakukan penelitian mengenai faktor-faktor yang mempengaruhi kelelahan pada pasien kanker yang menjalani kemoterapi serta pemberian intervensi komplementer, sehingga dapat ditemukan intervensi keperawatan komplementer yang paling efektif diberikan kepada pasien kanker yang menjalani kemoterapi untuk meminimalisir kelelahan efek kemoterapi.

\section{DAFTAR PUSTAKA}

Alam, A. (2018). Chemotherapy Treatment and Strategy Schemes: A Review. Open Access Journal of Toxicology, 2(5). https://doi.org/10.19080/oajt.2018.02.555600

American Cancer Society. (2019). Cancer Treatment and Survivorship Facts and Figures 2019-2021. Retrieved from https://www.cancer.org/research/cancer-factsstatistics/survivor-facts-figures.html

Dahlia, D., Karim, D., \& Damanik, S. R. H. (2019). Gambaran Fatigue pada Pasien Kanker Post Kemoterapi. Jurnal Ners Indonesia, 9(2), 80. https://doi.org/10.31258/jni.10.1.80-93

Fabi, A., Bhargava, R., Fatigoni, S., Guglielmo, M., Horneber, M., Roila, F., \& Ripamonti, C. I. (2020). Cancer-Related Fatigue: ESMO Clinical Practice Guidelines for diagnosis and treatment. Annals of Oncology, 31(6), 713-723. https://doi.org/10.1016/j.annonc.2020.02.016

Globocan. (2018). Cancer Today. International Agency for Reseacrh on Cancer. Retrieved from http://gco.iarc.fr/

Khairani, S., Keban, S. A., \& Afrianty, M. (2019). Evaluation of Drug Side Effects Chemotherapy on Quality of Life (QOL) Breast Cancer Patients at Hospital X in Jakarta. Jurnal Ilmu Kefarmasian Indonesia, 17(1), 9. https://doi.org/10.35814/jifi.v17i1.705

Khanghah, A. G., Rizi, M. S., Nabi, B. N., Adib, M., \& Leili, E. K. N. (2019). Effects of Acupressure on Fatigue in Patients with Cancer Who Underwent Chemotherapy. JAMS Journal of Acupuncture and Meridian Studies, 12(4), 103-110. https://doi.org/10.1016/j.jams.2019.07.003

Marco, M. D., Rubbi, I., Baldi, A., Lorenzo, R. D., Magnani, D., Cremonini, V., \& Ferri, P. (2018). Evaluation of Fatigue in Patients with Pancreatic Cancer Receiving Chemotherapy Treatment: A Cross-Sectional Observational Study. Acta Biomedica, 89(4), 18-27. https://doi.org/10.23750/abm.v89i4-S.7063

Menga, M. K., Sjattar, E. L., \& Irwan, A. M. (2020). Analisis Faktor yang Mempengaruhi Fatigue pada Pasien Kanker dengan Kemoterapi: Literatur Review. Juiperdo: Jurnal Ilmiah Perawat Manado, 8(02), 47-64. https://ejurnal.poltekkes-manado.ac.id/index.php/juiperdo/article/view/1235

Muis, M. R., Nasution, M. I., Azhar, M. E., \& Radiman, R. (2018). Pengaruh Kepemimpinan dan Self Efficacy terhadap Kelelahan Emosional Serta Dampaknya terhadap Kepuasan Kerja Dosen. Jurnal Riset Sains Manajemen, 2(3), 131-142. https://doi.org/10.5281/zenodo.1477532

Network, N. C. C. (2018). NCCN Clinical Practice Guidelines in Oncology. https://www.nccn.org/guidelines/category_1 
Nitalia, T. I. (2019). Hubungan antara Tingkat nyeri dengan Fatigue pada Pasien Kemoterapi di Ruang Flamboyan Rumah Sakit Baladhika Husada Jember Universitas Jember. http://repository.unej.ac.id/handle/123456789/91081

O'Regan, P., McCarthy, G., O'Reilly, S., Power, D., Bird, B. H., Murphy, C. G., \& Hegarty, J. (2019). Cancer-Related Fatigue and Self-Care Agency: A Multicentre Survey of Patients Receiving Chemotherapy. Journal of Clinical Nursing, 28(2324), 4424-4433. https://doi.org/10.1111/jocn.15026

Pawicara, R., \& Conilie, M. (2020). Analisis Pembelajaran Daring terhadap Kejenuhan Belajar Mahasiswa Tadris Biologi IAIN Jember di Tengah Pandemi Covid-19. Alveoli: Jurnal Pendidikan Biologi, 1(1), 29-38. https://doi.org/10.35719/alveoli.v1i1.7

Rahma,D. A., \& Ikhsanuddin, A. H. (2021). Kelelahan pada Pasien Kanker yang Menjalani Keoterapi di RSUP H. Adam Malik Medan. Universitas Sumatera Utara. https://repositori.usu.ac.id/handle/123456789/44660

Strebkova, R., Petkova, M., \& Minev, M. (2017). Assessment of Cancer Related Fatigue. Trakia Journal of Sciences, 15(3), 238-243. DOI: 10.15547/tjs.2017.03.010

Wang, Y. Q., Cao, H. P., Liu, X., Yang, Z., Yin, Y. Y., Ma, R. C., \& Xie, J. (2020). Effect of Breathing Exercises in Patients with Non-Small Cell Lung Cancer Receiving Surgical Treatment: A Randomized Controlled Trial. European Journal of Integrative Medicine, 38(July 2020), 101175. https://doi.org/10.1016/j.eujim.2020.101175

Yayasan kanker indonesia. (2019). Apa itu Kanker. Retrieved from http://yayasankankerindonesia.org/apa-itu-kanker 